\title{
From intermittent to persistent cyanobacterial blooms: identifying the main drivers in an urban tropical reservoir
}

\author{
Cleber C. FIGUEREDO, ${ }^{1}$ Ricardo M. PINTO-COELHO,${ }^{2}$ Ana Maria M.B. LOPES, ${ }^{1}$ Pedro H.O. LIMA,${ }^{1}$ Björn GÜCKER, ${ }^{3}$ \\ Alessandra GIANI ${ }^{*}$ \\ ${ }^{1}$ Departamento de Botânica, Instituto de Ciências Biológicas, Universidade Federal de Minas Gerais (UFMG), PO Box 486, $31270-$ \\ 010, Belo Horizonte, MG; ${ }^{2}$ Departamento de Biologia Geral, Instituto de Ciências Biológicas, Universidade Federal de Minas Gerais \\ (UFMG), PO Box 486, 31270-010, Belo Horizonte, MG; ${ }^{3}$ Departamento de Geociências, Campus Tancredo de Almeida Neves, \\ Universidade Federal de São João del-Rei, 36301-360, São João del-Rei, MG, Brazil \\ *Corresponding author: agiani@icb.ufmg.br
}

\begin{abstract}
Eutrophication has impacted water bodies around the world. Knowledge on how to manage and restore these systems is urgently needed in order to maintain adequate water quality. However, causes and consequences of eutrophication may differ among lakes located in tropical and temperate regions. The eutrophication process is better understood for temperate lakes due to the availability of a larger number of studies and longer time-series of data sets. In tropical regions, long-term studies are rare, but could exemplify the particularities of eutrophication speed under conditions of higher temperatures. The purpose of this work was to analyze the evolution of the eutrophication process in an urban tropical reservoir, using a 15-year time series (with occasional interruptions). The dataset comprised monthly sampling of several environmental variables and the phytoplankton community. We found a continuous process of water quality deterioration, mainly related to increasing levels of nutrient and phytoplankton biomass, as well as decreasing water transparency, even after the installation of a municipal wastewater treatment plant. The ongoing eutrophication resulted in a steep trend of increasing cyanobacteria biomass that turned from a seasonal appearance into more persistent blooms in the most recent decades, while the relative contribution of other algal phyla to total phytoplankton biomass declined, which resulted in a loss of phytoplankton diversity. Phosphorus was the major determinant of the persistent blooms. Even though nitrogen concentrations were very high in this system, they were not significantly correlated with phytoplankton or cyanobacteria biomass. Total-P concentrations increased about three times during the study period, indicating that the reservoir did not respond to recent restoration efforts. The average water temperature, always sufficiently high to allow phytoplankton growth all year round, is an additional factor that makes tropical reservoirs especially sensitive to eutrophication. In contrast to temperate systems, the constantly favorable temperatures in the tropics may facilitate the persistence and dominance of cyanobacteria in the plankton community.
\end{abstract}

Key words: Eutrophication; long-term studies; cyanobacteria; bloom stability; tropical reservoirs; wastewater treatment.

Received: September 2015. Accepted: March 2016.

\section{INTRODUCTION}

Along the last decades, cultural eutrophication has become a worldwide phenomenon, adversely affecting freshwater ecosystems (Zohary, 2004). It has promoted excessive phytoplankton growth and dominance of cyanobacteria, a group especially harmful because of its ability to produce potent toxins (Lagos et al., 1999; Carmichael et al., 2001). The occurrence of seasonal or sporadic algal blooms is generally the typical condition, but persistent cyanobacteria blooms are becoming more common (McGreggor and Fabbro, 2000; Roelke and Buyukates, 2002; Figueredo and Giani, 2009), increasing concerns regarding the eutrophication of surface waters in recent years.

Several studies have discussed the mechanisms that control phytoplankton dynamics, and some patterns have been recognized for both temperate and tropical freshwa- ter bodies, such as predictable temporal patterns determined by cyclic meteorological conditions (Talling, 1986; Giani, 1994; Figueredo and Giani, 2001; Sommer et al., 2012; de Senerpont Domis et al., 2013). Besides the description of more or less predictable changes in the phytoplankton community, these studies have also supported the development of theoretical and empirical models that identify the environmental variables determining phytoplankton patterns. These models generally point to resource availability as one of the major factors governing the dynamics of phytoplankton communities (Anneville et al., 2004). Nutrients play a special role in structuring phytoplankton and nutrient availability can vary seasonally, directly influenced by climate patterns (Paerl, 1988; Arhonditsis et al., 2004). Therefore, understanding lake nutrient dynamics is a critical prerequisite for management strategies, such as the implementation of wastewater treatment plants. Wastewater treatment often focuses on 
the control of phosphorus inputs, since this nutrient has been considered the most effective in promoting eutrophication (Bartram et al., 1999; Schelske et al., 2006). The view of lakes as essentially phosphorus limited ecosystems was defined by Sterner (2008) as the phosphorus limitation paradigm. However, this author also mentioned that co-limitation with $\mathrm{N}$ or other nutrients may be common. If nutrients can generate distinct feedbacks depending on the conditions of the water body, different phytoplankton species can also show distinct responses to environmental conditions. Phytoplankton community biomass and structure are useful variables to evaluate temporal changes in water quality, but the predictability of biological community dynamics is thought to be better for species groups (like Classes or Phyla) rather than for individual species (Evans, 1988). Therefore, higher taxonomic levels could maintain stable temporal patterns under similar meteorological cycles, even if changes could still be observed in terms of community composition, and predictability on species or genus level would be low (Sommer et al., 2012). From a temporal point of view, predictions are in general more reliable over short periods of time, generally characterized by small changes in environmental conditions. On longer time scales, the probability of occurrence of disturbances, which can lead to substantial changes in lake water quality, is higher (Zohary, 2004). Thus, considerable and unpredictable changes in phytoplankton composition become more likely. Long-term monitoring of freshwater systems is important to correctly evaluate their water quality (Hobbie et al., 2003), or to follow the progressive degradation of their ecological integrity. Such studies are rare in the tropics (Pinto-Coelho, 1998; Crossetti et al., 2008), since investments in developing and emerging tropical countries are traditionally made in attempts to solve existing waterquality problems, rather than preventing future ones. As a result, many tropical freshwater environments are only studied intermittently. However, the compilation of data from several short-term surveys is often useful to evaluate the system on a long-term scale.

In this study, we assessed interannual variations in water quality variables and the phytoplankton community in a tropical urban reservoir in southeastern Brazil. We compared periods before (1993-1996) and after (20102011) the implementation of a primary wastewater treatment plant (ETAF-Pampulha), which was installed in 2003.

\section{METHODS}

Pampulha reservoir is an urban reservoir created in 1938 by the damming of eight streams and located in the

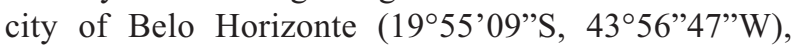
Brazil. Its mean depth is $5.1 \mathrm{~m}$ and a maximum depth around $16.2 \mathrm{~m}$ can be found in a small, deeper area near the dam. Its catchment area is about $100 \mathrm{~km}^{2}$ and the reservoir has a real surface area of about $1.8 \mathrm{~km}^{2}$, since about a third of its surface area was lost due to siltation processes (Giani et al., 1988). It has been heavily affected by human activities that resulted in its poor water quality and the appearance of cyanobacteria blooms. The reservoir is influenced by the region's seasonality, characterized by a warm and rainy season from November to March and a distinct dry season, with lower temperatures, from June to August. Two transitional periods between dry and rainy seasons are also observed in September/October and April/May. With the goal of decreasing the nutrient inputs, a wastewater treatment plant was implanted and began operating in 2003, but it is restricted to the primary treatment of the water of only the two larger and more polluted tributaries to the reservoir (Ressaca and Sarandi streams). Both streams contribute around $70 \%$ to the water that flows into the reservoir. To describe the evolution of this ecosystem, we have contrasted water quality and phytoplankton data obtained in recent years (January 2010 to December 2011) with those already reported and obtained between 1993 and 1996 (Pinto-Coelho, 1998; Giani and Figueredo, 1999; Figueredo and Giani, 2001).

Phytoplankton community and water quality data were obtained by monthly sampling in a site located near the central pelagic area of the reservoir (station E05, maximum depth $7 \mathrm{~m}$ ), which had already been used in previous studies performed in the reservoir (Pinto-Coelho, 1998; Giani and Figueredo, 1999; Figueredo and Giani, 2001). This site is ideal for long-term comparison studies due to the relatively large database available. In situ profiles of temperature, electrical conductivity and dissolved oxygen (DO) were obtained at $0.5 \mathrm{~m}$ depth intervals with a multiparameter probe (YSI 556 MPS). A standard Secchi disk was used to estimate water transparency and the depth of euphotic zone $\left(Z_{e}\right)$, which was calculated by multiplying the Secchi depth value by 2.5 . Water samples were collected using a Van Dorn bottle at Secchi depth (representing the euphotic zone). Physical, chemical and phytoplankton analyses were performed as described previously (Pinto-Coelho, 1998; Giani and Figueredo, 1999; Figueredo and Giani, 2001). Total phosphorus (TP) was used for long-term comparisons, since it is considered the variable that best represents the actual phosphorus availability, and thus the system's trophic state (Dodds, 2003). The sum of ammonium and nitrate was expressed as dissolved inorganic nitrogen (DIN) and used to describe the nitrogen pool. Annual mean values of physical, chemical and biological variables were calculated to evaluate potential effects of the wastewater treatment plant implementation. The species diversity of the phytoplankton community was calculated by the Shannon-Wiener index, according to the formula:

$\mathrm{H}^{\prime}=-\sum\left(\right.$ pi $\log _{2}$ pi $)$ 
Where $p i$ is calculated for each species and represents the proportion between its biovolume and the total phytoplankton biovolume in the sample.

Temporal patterns in the data were analysed using linear mixed-effect models. The response variables Secchi depth, water temperature, electrical conductivity, dissolved oxygen, total phosphorus, ammonium, and nitrate were analysed separately as a function of the fixed factor sampling year and the random factor sampling month, and their interaction (sampling year $\times$ sampling month). The function lme of the package nlme within the software $\mathrm{R}$ (R Development Core Team 2014) was used for these analyses. Distributions of residuals were analysed to select the most appropriate models (Zuur et al., 2009). To achieve homogeneous distributions of residuals, the response variables total phosphorus, ammonium, and nitrate were $\log _{10}(\mathrm{x}+1)$-transformed prior to analysis. Pairwise comparisons among sampling years were performed with Fisher's LSD post-hoc test. More specific comparisons were performed for nutrients and also for the biological data set (phytoplankton), which were obtained in 1996, 2010 and 2011. The main trends were explored by performing a principal component analysis (PCA), which also allowed for the identification of the key variables responsible for the observed patterns. For this data set, we also calculated linear mixed-effect models, following the previously described methods. To evaluate specific relationships between biological variables (total biovolume, cyanobacteria biovolume and Shannon-Wiener diversity), Secchi depth and nutrients $\left(\mathrm{NH}_{4}{ }^{+}, \mathrm{NO}_{3}{ }^{-}\right.$and total-P), data were $\log$ transformed to attain normality. Pearson correlations were performed for the 7 variables with $n=35$ observations (JMP ${ }^{\circledR}$ SAS Institute software).

\section{RESULTS}

Fig. 1 shows the annual trends of the studied physical and chemical variables. Linear mixed-effect models comparing these variables among years (1993-1996 to 20102011) are summarized in Tab. 1. Dissolved oxygen neither showed significant differences among sampling years nor differences among sampling months (Tab. 1, Fig. 1a). Water temperature showed significant, but nonsystematic differences among sampling years (Table 1, Fig. 1b). However, there was a pronounced seasonality in water temperature, with higher water temperatures in months of the rainy season (Tab. 1). Electrical conductivity showed a weak trend towards higher values along the study period (Fig. 1c). However, seasonality, i.e. differences among sampling months, was much stronger
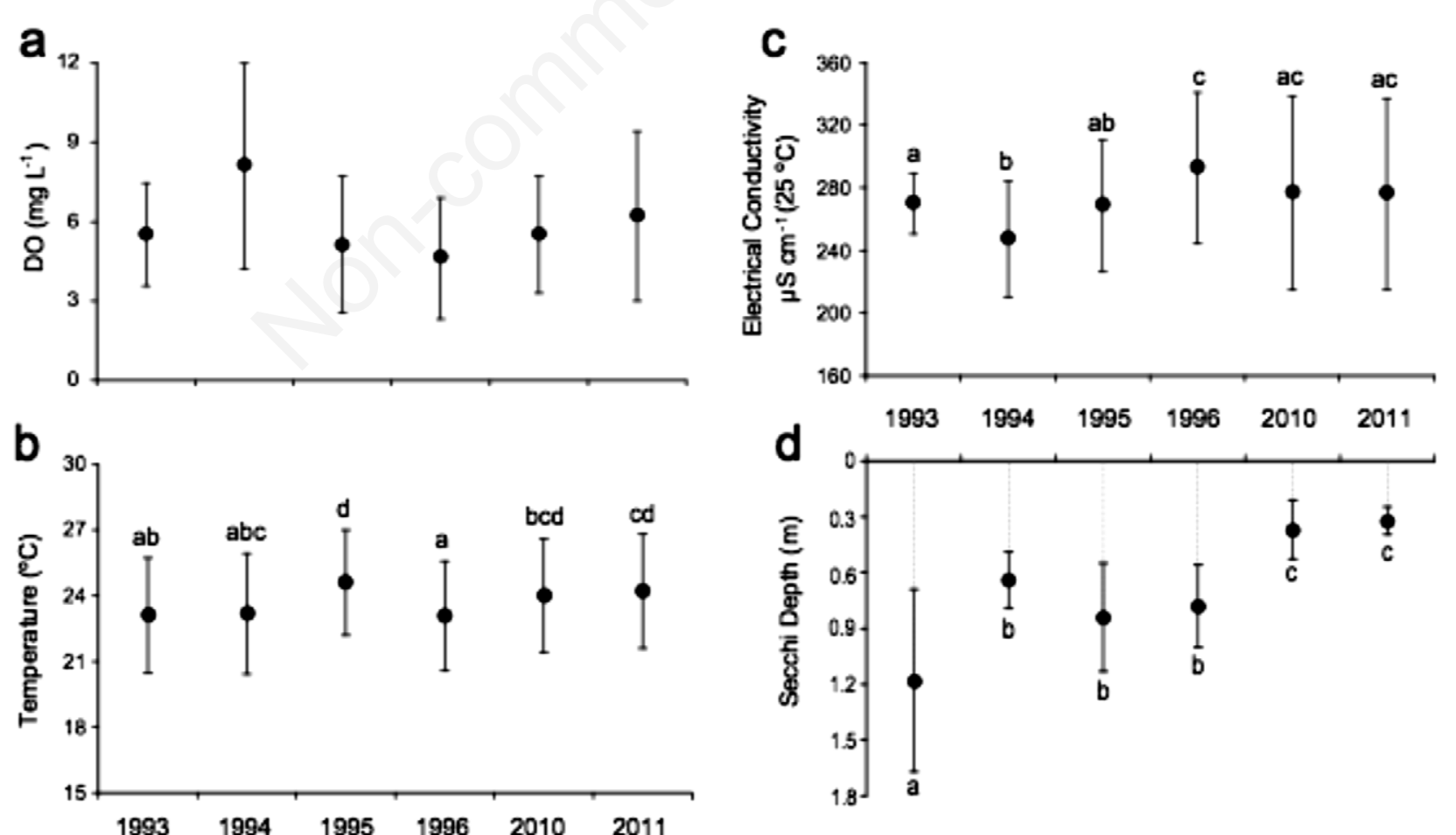

Fig. 1. Annual mean values of physical and chemical parameters in Pampulha reservoir in 1993-1996 and 2010-2011. Bars indicate standard deviation. See Tab. 1 for complete linear mixed-model statistics. Distinct letters above or below bars indicate differences among years, according to Fisher's LSD post-hoc tests. 
than this trend (Tab. 1). A strong interaction effect between both factors occurred (Tab. 1), because the observed trend towards higher values along the study period was most pronounced in months of the dry season. Secchi depth exhibited a strong temporal trend towards lower depths along the study period (Fig. 1d) and differences among years were stronger than differences among sampling months, i.e. seasonality (Tab. 1). Here, we also observed a strong interaction effect between both factors (Tab. 1), because the observed trend was most pronounced in months of the dry season.

With regard to nutrients (Fig. 2a), the ammonium and nitrate concentrations showed no significant changes between 1996 and 2010-2011 (mixed-effect models in Tab. 1, Fisher's LSD post-hoc test, $\mathrm{P}>0.05$ ). However, non-systematic differences among other sampling years were detected (Tab. 1). A clear long-term trend was observed for total-P concentration, which exhibited a continuous increase, resulting in values five times higher in 2011 than in 1996 (Fig. 2a). This long-term trend was stronger than seasonality, i.e. the differences among sampling months (Tab. 1). In 2010-2011, cyanobacteria were the main group representing over $80 \%$ of the total phytoplankton biovolume (average total biovolume of $29.2 \mathrm{~mm}^{3} \mathrm{~L}^{-1}$ ), while other phytoplanktonic groups made just minor contributions (Fig. 2b). The most representative cyanobacteria species were Microcystis aeruginosa Kützingemend Elekin, Sphaerocavum brasiliense Azevedo and Sant'Anna, and Cylindrospermopsis raciborskii (Woloszyn- ska) Seenaya et Subba Raju. The intermittency of blooms as registered in the 1990s, here represented by 1996, when cyanobacteria dominated only from September to November, was lost in more recent years (2010 and 2011), and cyanobacteria turned into the dominant group during the whole annual cycle (Fig. 2a). We found significant differences between the two compared periods (1996 vs 20102011) for both total phytoplankton biomass $(\mathrm{F}=26.8$, $\mathrm{P}<0.001)$ and cyanobacteria biomass $(\mathrm{F}=30.6, \mathrm{P}<0.001)$. In recent years, only few species dominated the entire community and, as a result, species diversity also decreased (Fig. 2c). During 2010-2011, low values in Shannon's diversity index became frequent. The annual pattern of the diversity index with lower values during the sporadic cyanobacteria bloom disappeared, and diversity was relatively low throughout the year.

Considering the fundamental role of nutrients and light in controlling phytoplankton dynamics, we compared Secchi depth and concentrations of ammonium, nitrate and total-P in 1996 with the 2010-2011 data series, on a monthly basis. In general, $\mathrm{N}$ and $\mathrm{P}$ concentrations had always been high in Pampulha reservoir, but highest concentrations were generally observed in the transition periods between dry and rainy season. The recently recorded concentration of total-P (2010 to 2011) was significantly higher than that observed in $1996(\mathrm{~F}=25.0$, $\mathrm{P}<0.001)$. However, both inorganic nitrogen species $\left(\mathrm{NH}_{4}^{+}\right.$and $\left.\mathrm{NO}_{3}^{-}\right)$were not significantly different between the two periods $(\mathrm{F}=0.3, \mathrm{P}=0.583$ for ammonium and

Tab. 1. Summary of linear mixed effects models for Secchi depth, water temperature, conductivity, dissolved oxygen, total phosphorus, ammonium and nitrate.

\begin{tabular}{|c|c|c|c|c|c|c|}
\hline Response variable & Effect & SS & Df & Ms & $\mathbf{F}$ & $\mathbf{P}$ \\
\hline Secchi & $\begin{array}{l}\text { Year (fixed) } \\
\text { Month (random) } \\
\text { Year x month (random) }\end{array}$ & $\begin{array}{l}95541 \\
26811 \\
75707\end{array}$ & $\begin{array}{r}5 \\
11 \\
55\end{array}$ & $\begin{array}{r}19108 \\
2437 \\
1376\end{array}$ & $\begin{array}{r}13.9 \\
1.8 \\
275300\end{array}$ & $\begin{array}{l}0.0000 * * \\
0.0821 \\
0.0000 * *\end{array}$ \\
\hline Temperature & $\begin{array}{l}\text { Year (fixed) } \\
\text { Month (random) } \\
\text { Year x month (random) }\end{array}$ & $\begin{array}{r}59.9 \\
763.5 \\
175.7 \\
\end{array}$ & $\begin{array}{r}5 \\
11 \\
55\end{array}$ & $\begin{array}{r}11.99 \\
69.41 \\
3.19 \\
\end{array}$ & $\begin{array}{r}3.75 \\
21.73 \\
638.97 \\
\end{array}$ & $\begin{array}{l}0.0054 * * \\
0.0000 * * \\
0.0000 * *\end{array}$ \\
\hline DO & $\begin{array}{l}\text { Year (fixed) } \\
\text { Month (random) } \\
\text { Year x month (random) }\end{array}$ & $\begin{array}{l}144.1 \\
207.6 \\
730.0\end{array}$ & $\begin{array}{r}5 \\
11 \\
55\end{array}$ & $\begin{array}{l}28.82 \\
18.88 \\
13.27 \\
\end{array}$ & $\begin{array}{r}2.17 \\
1.42 \\
2654\end{array}$ & $\begin{array}{l}0.0705 \\
0.1896 \\
0.0000^{* *}\end{array}$ \\
\hline $\log (\mathrm{TP}+1)$ & $\begin{array}{l}\text { Year (fixed) } \\
\text { Month (random) } \\
\text { Year x month (random) }\end{array}$ & $\begin{array}{l}8.2 \\
3.7 \\
2.6\end{array}$ & $\begin{array}{r}5 \\
11 \\
55\end{array}$ & $\begin{array}{l}1.64 \\
0.34 \\
0.05\end{array}$ & $\begin{array}{r}34.68 \\
7.19 \\
9.45\end{array}$ & $\begin{array}{l}0.0000 * * \\
0.0000 * * \\
0.0000 * *\end{array}$ \\
\hline $\log \left(\mathrm{NH}_{4}+1\right)$ & $\begin{array}{l}\text { Year (fixed) } \\
\text { Month (random) } \\
\text { Year x month (random) }\end{array}$ & $\begin{array}{l}1.0 \\
4.1 \\
2.0\end{array}$ & $\begin{array}{r}5 \\
11 \\
55\end{array}$ & $\begin{array}{l}0.20 \\
0.38 \\
0.04\end{array}$ & $\begin{array}{r}5.70 \\
10.57 \\
7.10 \\
\end{array}$ & $\begin{array}{l}0.0003 * * \\
0.0000 * * \\
0.0000 * *\end{array}$ \\
\hline $\log \left(\mathrm{NO}_{3}+1\right)$ & $\begin{array}{l}\text { Year (fixed) } \\
\text { Month (random) } \\
\text { Year x month (random) }\end{array}$ & $\begin{array}{r}7.3 \\
22.0 \\
25.6\end{array}$ & $\begin{array}{r}5 \\
11 \\
55\end{array}$ & $\begin{array}{l}1.47 \\
2.00 \\
0.47\end{array}$ & $\begin{array}{r}3.16 \\
4.31 \\
93.00\end{array}$ & $\begin{array}{l}0.0141 * \\
0.0001 * * \\
0.0000 * *\end{array}$ \\
\hline
\end{tabular}

SS, sum of squares; $D f$, degrees of freedom; $M$ s, mean square; $\mathrm{DO}$, dissolved oxygen; $\mathrm{TP}$, total phosphorus; $\mathrm{NH}_{4}$, ammonium; $\mathrm{NO}_{3}$, nitrate. 
$\mathrm{F}=0.2, \mathrm{P}=0.658$ for nitrate). On the other hand, Secchi disk values were significantly lower in recent years than in $1996(\mathrm{~F}=74.8, \mathrm{P}<0.001)$. The importance of these variables to explain water quality changes in Pampulha reservoir was also highlighted by the PCA, which pointed out nutrients and phytoplankton as key variables (Fig. 3). They were able to explain $90 \%$ of the total environmental variability in the reservoir, from 1996 to 2010-2011. The $1^{\text {st }}$ factor explained $51.1 \%$ of the total variability and was associated with total-P, phytoplankton and Secchi transparency, thus describing the increasing eutrophication of the system. The two periods were clearly distinguished by their trophic status, confirming the strong hypereutrophic conditions in 2010-2011 (Fig. 3). Factor 2 explained $38.1 \%$ of the total variability, and was mainly associated with nitrogen sources $\left(\mathrm{NH}_{4}^{+}\right.$and $\left.\mathrm{NO}_{3}{ }^{-}\right)$and, therefore, probably reflected the seasonality of the system, since these variables had a very repetitive, although opposite, annual oscillation pattern in all the years evaluated in this study (data not shown).

Cyanobacteria showed significant $(\mathrm{P}<0.001, \mathrm{n}=35)$, negative correlation with Secchi depth $(\mathrm{r}=-0.781)$ and
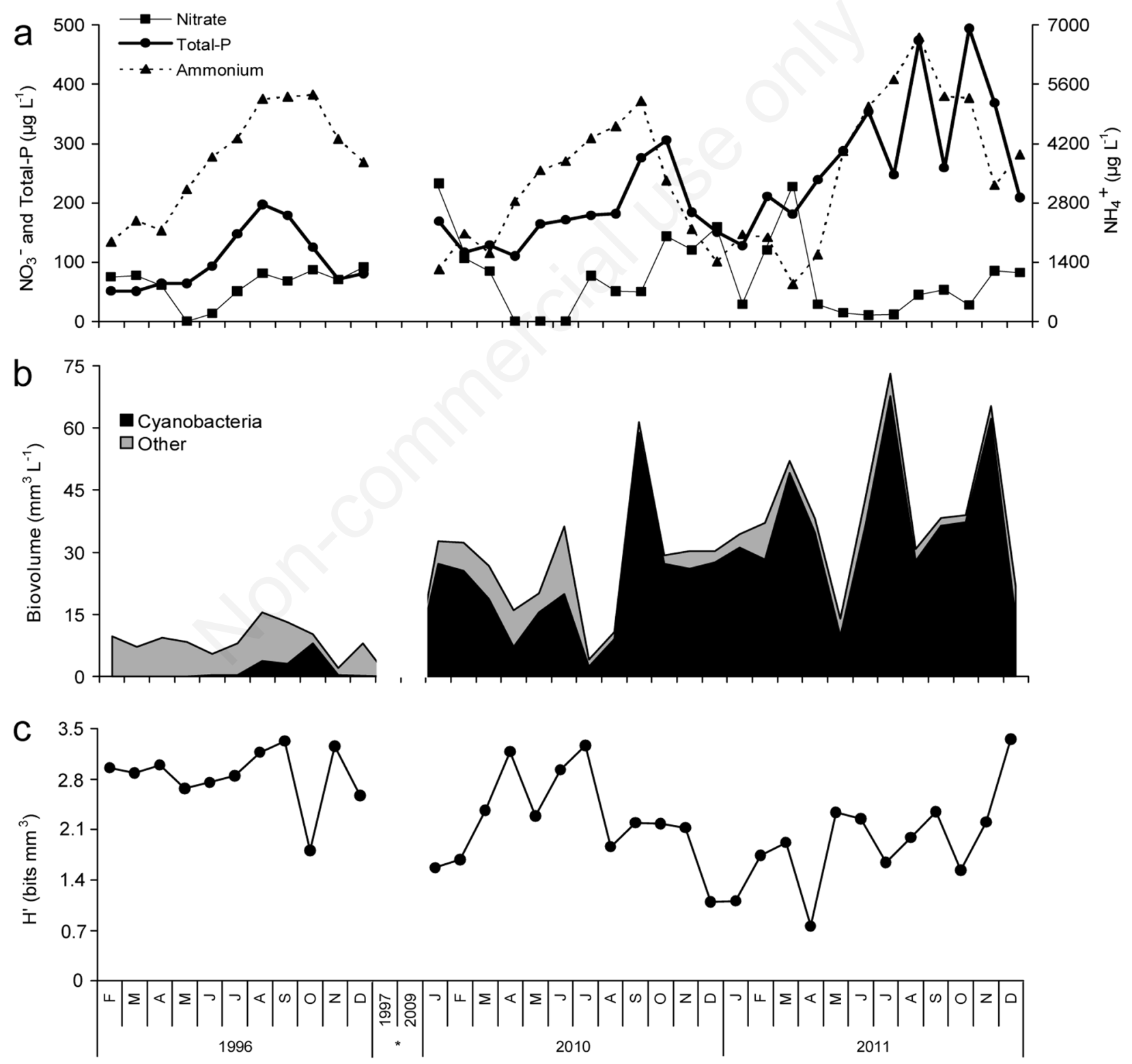

Fig. 2. Monthly recorded values of (a) nutrients (nitrate, ammonium and total phosphorus); (b) biovolume of cyanobacteria and other phytoplankton taxa; (c) Shannon-Wiener diversity, in Pampulha reservoir during 1996, 2010 and 2011. 
positive correlation with total phosphorus $(\mathrm{r}=0.785)$ (Fig. 4). No significant correlations were found with nitrogen sources $\left(\mathrm{NO}_{3}^{-}, \mathrm{NH}_{4}^{+}, \mathrm{P}>0.20\right)$. Because cyanobacteria were the most important phytoplankton group, similar results were observed for total phytoplankton biomass (Secchi depth: $r=-0.820$; TP: $r=0.673$ ). Shannon-Wiener diversity was negatively correlated to cyanobacteria biomass $(r=-0.620, P<0.001)$. Temperature was not significantly correlated with cyanobacteria $(\mathrm{P}=0.341)$ or total phytoplankton biomass $(\mathrm{P}=0.259)$. This was expected since, as shown in Fig. 1b, no significant trend of temperature increase was observed from 1993 to 2011 in the reservoir.

\section{DISCUSSION}

\section{Nutrient trends in Pampulha reservoir}

Although the growth of phytoplankton depends on many bottom-up and top-down forces, the availability of nutrients, especially $\mathrm{P}$ and $\mathrm{N}$, is often a key factor determining the occurrence of blooms and their magnitude (Downing et al., 2001; Giani et al., 2005). Ammonium was the major inorganic $\mathrm{N}$ form in Pampulha reservoir, but did not exhibit evident long-term patterns. The same was observed for nitrate. Phosphorus also occurred at high concentrations, but it displayed a continuous increase over the years. In a previous study, Pinto-Coelho (1998) already drew attention to this problematic situation, describing the continuous phosphorous increase in this reservoir.

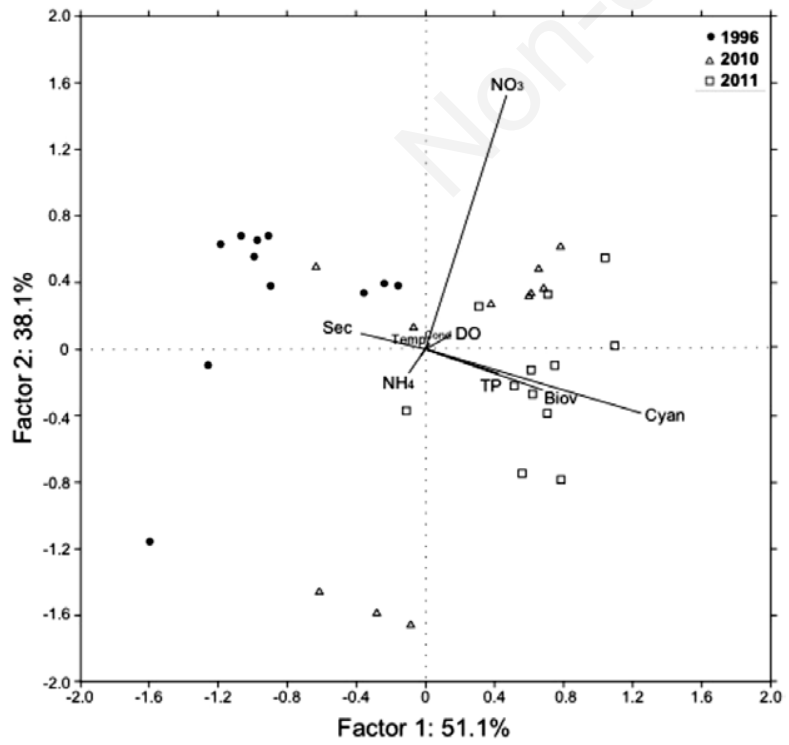

Fig. 3. PCA ordination for environmental physical, chemical and phytoplankton variables monthly obtained in Pampulha reservoir along 1996 (circles), 2010 (triangles) and 2011 (squares).
However, the trend persisted in the following years, causing the occurrence of massive cyanobacteria blooms and their more stable permanence.

The increasing TP concentrations in the reservoir in recent years can be explained by the following reasons: First, the wastewater treatment plant performs primary treatment (i.e., no inorganic nutrient removal) of the water of only two (Ressaca and Sarandi) out of the eight streams flowing into the reservoir (Coutinho, 2007). Considering this limited operational capacity, we could not expect significant changes after the installation of the plant, which is evident from observing nutrient and phytoplankton data describing a continuous and intense eutrophication process. An increasing TP input may also be explained by a higher contribution from untreated streams (those that are not primarily treated by the treatment plant) as a consequence of a growing urbanization and more dense population in the reservoir's catchment (source: www.ibge.gov.br - accessed on January 2013). Finally, the internal P recycling rate from the sediments may also contribute to higher TP concentrations due to more episodes of low DO concentrations and even hypoxia in the hypolimnion in recent years (Friese et al., 2010). A similar situation was observed in Lake Kinneret, Israel (Zohary, 2004), where external nutrient inputs declined, but internal loading and recycling were important to maintain the already altered phytoplankton community. Finally, massive sediment inputs caused by superficial erosion have been associated with $\mathrm{P}$ accumulation in Pampulha reservoir (Torres et al., 2007) and could represent another important P source.

\section{Drivers of cyanobacterial blooms}

The specific importance of different nutrients in the eutrophication process is heavily debated (Xu et al., 2010; Abell et al., 2010), but the basal connection between $\mathrm{P}$ and phytoplankton biomass is widely recognized for freshwater environments (OECD, 1982). The massive increase of $\mathrm{P}$ concentration in Pampulha reservoir during the last decades seems to have been the critical factor to establish optimal conditions fostering the constant and excessive cyanobacterial biomass. Total-P level is considered one of the major factors determining cyanobacteria dynamics (Carvalho et al., 2011). Downing et al. (2001), for example, suggested that cyanobacteria would probably dominate ecosystems with total-P levels higher than 100 $\mu \mathrm{gL}^{-1}$, which was a constant condition in Pampulha reservoir during the last few years. However, even if P proved to be essential to explain trends in Pampulha reservoir, we think that these results cannot be conclusive to support the phosphorus limitation paradigm (Sterner, 2008) - i.e. that $P$-only control can reverse cultural eutrophication for this tropical reservoir, because for decades the reservoir also had extremely high $\mathrm{N}$ concentrations. Thus, it is 
difficult to analyze the specific effects of $\mathrm{N}$ on local phytoplankton, because N-limitation conditions rarely occurred. Only after a potential $\mathrm{P}$ reduction in the system, will it be possible to evaluate the actual importance of $\mathrm{N}$ as a driver to cyanobacteria growth.

In general, the alternation between periods of cyanobacterial blooms and periods with lower cell densities across the seasons is a common feature in deteriorated freshwater environments, and a similar situation has been reported for Pampulha reservoir in the past (Giani, 1994; Figueredo and Giani, 2001). Nevertheless, these seasonal cycles can be substituted by persistent blooms, as observed in several lentic ecosystems (McGreggor and Fabbro, 2000; Roelke and Buyukates, 2002), including our results for Pampulha reservoir in recent years. The massive growth of cyanobacteria can be predictable to some extent and authors have tried to hierarchically rank the environmental variables according to their importance for bloom appearance (Paerl, 1988; Mowe et al., 2015). For temperate regions, climate and nutrients are essential in controlling cyanobacteria blooms (Paerl, 1988; Carvalho et al., 2011; Fernandéz et al., 2015) and these major factors can show strong oscillations, as a consequence of seasonality. In the tropics, the situation
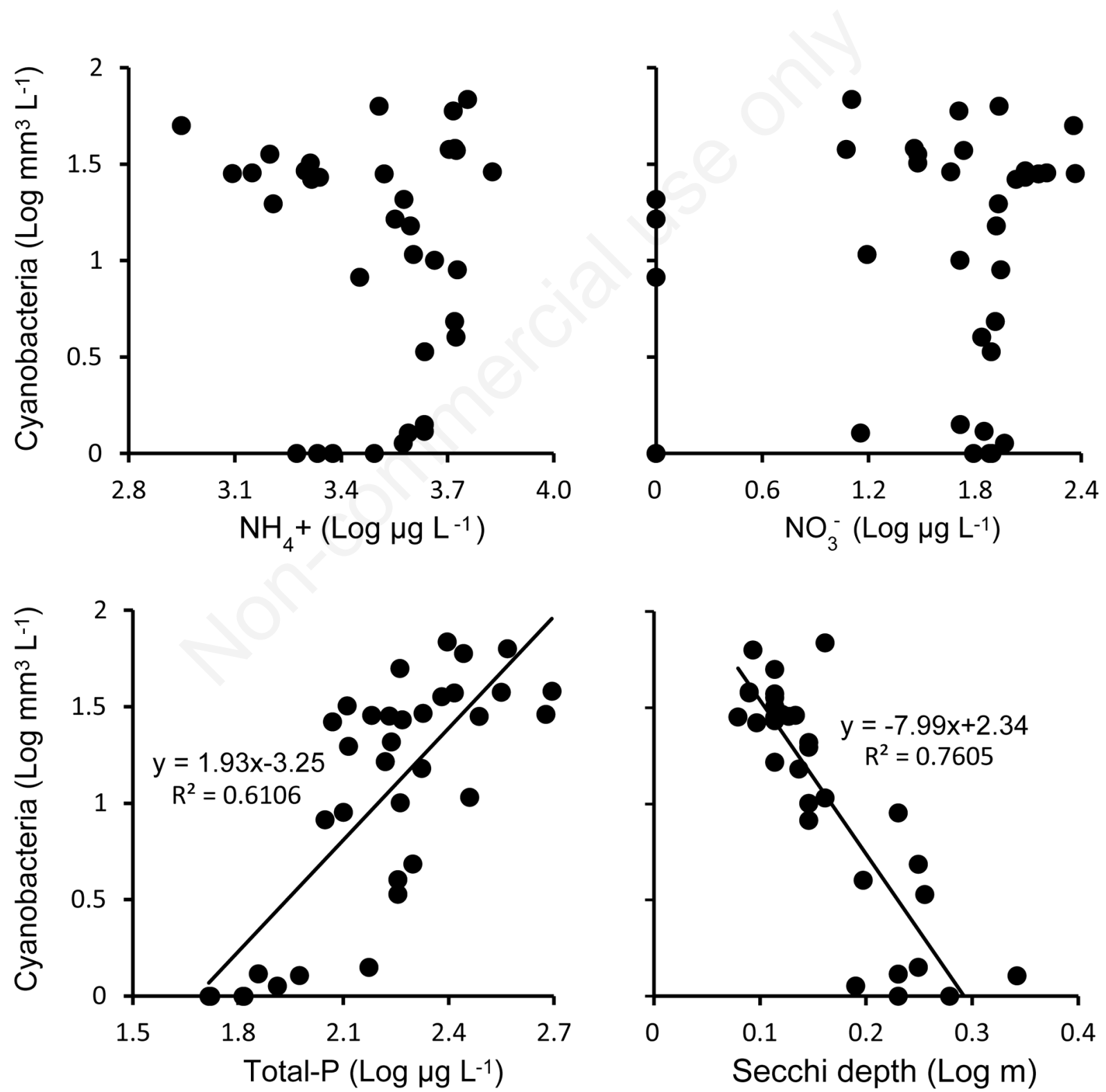

Fig. 4. Pearson correlations between cyanobacteria biomass and nutrients (ammonium, nitrate, total-P) and water transparency, in Pampulha reservoir in 1996 and 2010-2011. 
could be slightly different, since temperature and photosynthetic active radiation (PAR) show favourable levels throughout the year. However, seasonal trends can also be observed in the tropics and occur mainly by the indirect effects of rain on nutrient concentrations (Paerl, 1988; Figueredo and Giani, 2001; Arhonditsis et al., 2004; de Senerpont Domis et al., 2013). This suggests that conditions could be extremely favourable for phytoplankton growth in these regions, if nutrients reached sufficiently high concentrations to exceed the dilution capacity of the rain. The ultimate result would be the incidence of stable blooms, such as those observed in the Pampulha reservoir. In this ecosystem, the high levels of cyanobacteria were mainly formed by the two most common bloom-forming genera in South America: Cylindrospermopsis and Microcystis (Mowe et al., 2015).

At present, $\mathrm{P}$ levels in Pampulha reservoir are indeed high enough that rainfall is not sufficient to promote a significant dilution down to concentrations less favourable for cyanobacterial blooms. Fernandéz et al. (2015) also observed a strong connection between $\mathrm{P}$ concentrations and cyanobacteria blooms in an Argentinian hypereutrophic reservoir, but blooms were not persistent since low temperature was limiting phytoplankton development during winter. However, when light, temperature and nutrients are constantly favourable, we can expect some stability in the bloom occurrence, as already observed in studies in other tropical aquatic systems (Huszar et al., 2000; Nogueira, 2000). Not surprisingly, a simultaneous reduction of phytoplankton richness and diversity $\left(\mathrm{H}^{\prime}\right)$ is also observed. Thereby, blooms can severely damage freshwater life by direct and indirect effects (Williams et al., 2010; Figueredo and Giani, 2001; Roelke and Buyukates, 2002). Light is essential for phytoplankton development, however it can become limiting as a consequence of excessive cyanobacteria growth (Scheffer et al., 1997). The strong connection between water transparency and phytoplankton biomass found in our work suggests that the blooms were likely the cause of low water transparency. However, the permanence of cyanobacterial blooms could partially be explained by self-sustaining characteristics. Cyanobacterial blooms can create conditions, such as intense shading, which will favour their dominance over other phytoplankton species (Paerl, 1988; Briand et al., 2002), a phenomenon that could explain the decreasing phytoplankton diversity recorded in the last years in the reservoir. Human activities have adversely affected many freshwater systems around the world and this process is particularly intense in the developing and emerging countries (Kivaisi, 2001). In these regions, environmental monitoring studies are generally performed on a short-term basis, i.e., less than two years. Their purpose is to provide short-term answers to urgent problems (Rhoads and Germano, 1986). However, long-term and irreversible changes may affect human well-being more drastically than short-term environmental impacts (Rhoads and Germano, 1986). Moreover, long-term studies can provide data to help understanding ecological processes, and future responses to continuous nutrient input. Therefore, even though fragmentary, the dataset presented here allowed for the evaluation of long-term variations in water quality, and the identification of increasing $\mathrm{P}$ as the major factor causing a constantly high biomass and dominance of cyanobacteria. Currently, a population of around 350.000 inhabitants live in the Pampulha catchment area, and it was estimated that about $50 \%$ of the sewage produced was directly released into the streams that recharge into the reservoir (Coutinho, 2007). Recent demographic growth is possibly one of the major issues resulting in the degradation of the reservoir and efforts to minimize P loading are urgently needed in order to improve water quality.

\section{CONCLUSIONS}

In conclusion, our results pointed to Pampulha reservoir being a critically endangered water resource, due to years of pollution. Our study showed that eutrophication in tropical lentic systems can modify the seasonal tendencies by promoting community changes that ultimately culminate in very stable cyanobacteria blooms. We have also noticed that despite efforts made to restore Pampulha reservoir, the system has not shown a positive response. Clearly, the reservoir requires new attempts and greater investments for a successful recovery, for example by installing tertiary treatment plants, including chemical dosing for P stripping, to collect and treat all the sewage produced in the reservoir catchment area.

\section{ACKNOWLEDGMENTS}

This study was supported funds provided by the municipality of the city of Belo Horizonte to R.M.P.C. and A.G. (1993-1996) as well as by CNPq (Conselho Nacional de Pesquisa) and FAPEMIG (Fundação de Apoio a Pesquisa de Minas Gerais) to A.G. in the last years. We thank an anonymous reviewer for suggestions and improvements on this manuscript.

\section{REFERENCES}

Abell JM, Özkundakci D, Hamilton DP, 2010. Nitrogen and phosphorus limitation of phytoplankton growth in New Zealand lakes: implications for eutrophication control. Ecosystems 13:966-977.

Anneville O, Souissi S, Gammeter S, Straile D, 2004. Seasonal and interannual scales of variability in phytoplankton assemblages: comparison of phytoplankton dynamics in three peri-alpine lakes over a period of 28 years. Freshwater Biol. 49:98-115.

Arhonditsis GB, Winder M, Brett MT, Schindler DE, 2004. Pat- 
terns and mechanisms of phytoplankton variability in Lake Washington (USA). Water Res. 38:4013-4027.

Bartram J, Carmichael W, Chorus I, Jones G, Skulberg OM, 1999. Introduction. In: I. Chorus and J. Bartram (eds.), Toxic cyanobacteria in water: a guide to their public health consequences, monitoring and management. E\&FN Spon, London.

Briand JF, Robillot C, Quiblier-Llobéras C, Humbert JF, Couté A, Bernard C, 2002. Environmental context of Cylindrospermopsis raciborskii (Cyanobacteria) blooms in a shallow pond in France. Water Res. 36:3183-3192.

Carmichael WW, Azevedo SMFO, An JS, Molica RJR, Jochimsen EM, Lau S, Rinehart KL, Shaw GR, Eaglesham GK, 2001. Human fatalities from cyanobacteria: chemical and biological evidence for cyanotoxins. Environ. Health Persp. 109:663-668.

Carvalho L, Miller CA, Scott EM, Codd GA, Davies PS, Tyler AN, 2011. Cyanobacterial blooms: statistical models describing risk factors for national-scale lake assessment and lake management. Sci. Total Environ. 409:5353-5358.

Coutinho W, 2007. [Emprego da flotação a ar dissolvido no tratamento de cursos d'água - avaliação de desempenho da estação de tratamento dos córregos Ressaca e Sarandi, afluentes à Represa da Pampulha].[MSc Thesis in Portuguese]. Universidade Federal de Minas Gerais.

Crossetti LO, Bicudo DC, Bicudo CEM, Bini LM, 2008. Phytoplankton biodiversity changes in a shallow tropical reservoir during the hypertrophication process. Braz. J. Biol. 68:1061-1067.

de Senerpont Domis LN, Elser JJ, Gsel AS, Huszar VLM, Ibelings BW, Jeppesen E, Kosten S, Mooij WM, Roland F, Sommer U, Van Donk E, Winder M, Lürling M, 2013. Plankton dynamics under different climatic conditions in space and time. Freshwater Biol. 58:463-482.

Dodds WK, 2003. Misuse of inorganic N and soluble reactive $\mathrm{P}$ concentrations to indicate nutrient status of surface waters. J. N. Am. Benthol. Soc. 22:171-181.

Downing JA, Watson SB, McCauley E, 2001. Predicting Cyanobacteria dominance in lakes. Can. J. Fish. Aquat. Sci. 58:1905-1908.

Evans GT, 1988. A framework for discussing seasonal succession and coexistence of phytoplankton species. Limnol. Oceanogr. 33:1027-1036.

Fernández C, Estrada V, Parodi ER, 2015. Factors triggering cyanobacteria dominance and succession during blooms in a hypereutrophic drinking water supply reservoir. Water Air Soil Poll. 226:73.

Figueredo CC, Giani A, 2001. Seasonal variation in the diversity and species richness of phytoplankton in a tropical eutrophic reservoir. Hydrobiologia 445:165-174.

Figueredo CC, Giani A, 2009. Phytoplankton community in the tropical lake of Lagoa Santa (Brazil): Conditions favoring a persistent bloom of Cylindrospermopsis raciborskii. Limnologica 39:264-272.

Friese K, Schmidt G, de Lena JC, Nalini Jr HAN, Zachmann DW, 2010. Anthropogenic influence on the degradation of an urban lake - The Pampulha reservoir in Belo Horizonte, Minas Gerais, Brazil. Limnologica 40:114-125.

Giani A, 1994. Limnology in Pampulha Reservoir: some general observations with emphasis on the phytoplankton community, p. 151-164. In: R.M. Pinto-Coelho, A. Giani and E. von
Sperling (eds.), Ecology and human impact on lakes and reservoirs in Minas Gerais. SEGRAC, Belo Horizonte.

Giani A, Figueredo CC, 1999. [Recorrência de padrões sazonais do fitoplâncton num reservatório eutrófico (Reservatório da Pampulha, MG), p. 533-549]. In: R. Henry (ed.), [Ecologia de reservatórios: estrutura, função e aspectos sociais].[Book in Portuguese]. Fapesp / Fundbio, Botucatu.

Giani A, Bird D, Prairie Y, Lawrence J, 2005. Empirical study of cyanobacterial toxicity along a trophic gradient of lakes. Can. J. Fish. Aquat. Sci. 62:1-10.

Giani A, Pinto-Coelho RM, Oliveira SJM, Pelli A, 1988. [Ciclo sazonal de parâmetros físico-químicos da água e distribuição horizontal de nitrogênio e fósforo no reservatório da Pampulha (Belo Horizonte, MG, Brasil)].[Article in Portuguese]. Ciên. Cult. 40:69-77.

Hobbie JE, Carpenter SR, Grimm NB, Gosz JR, Seastedt TR, 2003. The US long term ecological research program. Bioscience 53:21-32.

Huszar VLM, Silva LHS, Marinho M, Domingos P, Sant'Anna CL, 2000. Cyanoprokaryote assemblages in eight productive tropical Brazilian waters. Hydrobiologia 424:67-77.

Kivaisi AK, 2001. The potential for constructed wetlands for wastewater treatment and reuse in developing countries: a review. Ecol. Eng. 16:545-560.

Lagos N, Onodera H, Zagatto PA, Andrinolo D, Azevedo SMFQ, Oshima Y, 1999. The first evidence of paralytic shellfish toxins in the freshwater cyanobacterium Cylindrospermopsis raciborskii, isolated from Brazil. Toxicon 37:1359-1373.

McGreggor GB, Fabbro LD, 2000. Dominance of Cylindrospermopsis raciborskii (Nostocales, Cyanoptokaryota) in Queensland tropical and subtropical reservoirs: implications for monitoring and management. Lakes Reserv. Res. Manage. 5:195-205.

Mowe MAD, Mitrovic SM, Lim RP, Furey A, Yeo DCJ, 2015. Tropical cyanobacterial blooms: a review of prevalence, problem taxa, toxins and influencing environmental factors. J. Limnol. 74:205-224.

Nogueira MG, 2000. Phytoplankton composition, dominance and abundance as indicators of environmental compartmentalization in Jurumirim Reservoir (Paranapanema River), São Paulo, Brazil. Hydrobiologia 431:115-128.

OECD, 1982. Eutrophication of waters. Monitoring, assessment and control. Organisation for Economic Co-operation and Development, Paris: 154 pp.

Paerl HW, 1988. Nuisance phytoplankton blooms in coastal, estuarine, and inland waters. Limnol. Oceanogr. 33:823-847.

Pinto-Coelho RM, 1998. Effects of eutrophication on seasonal patterns of mesozooplankton in a tropical reservoir: a 4-year study in Pampulha Lake, Brazil. Freshwater Biol. 40:159-173.

R Core Team, 2014. R: A language and environment for statistical computing. R Foundation for Statistical Computing, Vienna, Austria.

Roelke DL, Buyukates Y, 2002. Dynamics of phytoplankton succession coupled to species diversity as a system-level tool for study of Microcystis population dynamics in eutrophic lakes. Limnol. Oceanogr. 47:1109-1118.

Rhoads DC, Germano JD, 1986. Interpreting long-term changes in benthic community structure: a new protocol. Hydrobiologia 142:291-308. 
Scheffer M, Rinaldi S, Gragnani A, Mur LR, Nes EH, 1997. On the dominance of filamentous cyanobacteria in shallow turbid lakes. Ecology 78:272-282.

Schelske CL, Stoermer EF, Kenney WF, 2006. Historic lowlevel phosphorus enrichment in the Great Lakes inferred from biogenic silica accumulation in sediments. Limnol. Oceanogr. 51:728-748.

Sommer U, Adrian R, de Senerpont Domis LN, Elser JJ, Gaedke U, Ibelings B, Jeppesen E, Lürling M, Molinero JC, Mooij WM, Van Donk E, Winder M, 2012. Beyond the Plankton Ecology Group (PEG) Model: mechanisms driving plankton succession. Annu. Rev. Ecol. Evol. Syst. 43:429-448.

Sterner RW, 2008. On the phosphorus limitation paradigm for lakes. Int. Rev. Hydrobiol. 93:433-445.

Talling JF, 1986. The seasonality of phytoplankton in African lakes. Hydrobiologia 138:139-160.
Torres IC, Resck R, Pinto-Coelho RM, 2007. Mass balance estimation of nitrogen, carbon, phosphorus and total suspended solids in the urban eutrophic Pampulha reservoir, Brazil. Acta Limnol. Bras. 19:79-91.

Williams MR, Filoso S, Longstaff BJ, Dennison WC, 2010. Long-term trends of water quality and biotic metrics in Chesapeake Bay: 1986 to 2008. Estuar. Coast. 33:1279-1299.

Xu H, Paerl HW, Qin B, Zhu G, Gao G, 2010. Nitrogen and phosphorus inputs control phytoplankton growth in eutrophic Lake Taihu, China. Limnol. Oceanogr. 55:420-432.

Zohary T, 2004. Changes to the phytoplankton assemblage of Lake Kinneret after decades of a predictable, repetitive pattern. Freshwater Biol. 49:1355-1371.

Zuur AF, Ieno EN, Walker NJ, Saveliev AA, Smith GM, 2009. Mixed effects models and extensions in ecology with $R$. Springer-Verlag, New York: 574 pp. 